\title{
Pain evaluation in newborns using the Neonatal Facial Activity Coding scale during blood gases analysis*
}

\author{
Avaliação da dor do recém-nascido através da escala Codificação da Atividade Facial Neonatal \\ durante o exame de gasometria arterial
}

Isis de Oliveira Pinheiro' ${ }^{1}$, Francisca Elisângela Teixeira Lima ${ }^{1}$, Fernanda Jorge Magalhães ${ }^{1}$, Leiliane Martins Farias ${ }^{1}$, Maria do Socorro Mendonça Sherlock ${ }^{1}$

${ }^{*}$ Received from Federal University of Ceará, Nursing Department, Fortaleza, CE, Brazil.

DOI 10.5935/1806-0013.20150035

\section{ABSTRACT}

BACKGROUND AND OBJECTIVES: This study aimed at evaluating pain of newborns submitted to blood gases analysis by means of the Neonatal Facial Activity Coding scale, as well as at comparing newborns' physiological parameters before and during arterial puncture.

METHODS: This was an exploratory, descriptive and cross-sectional study with 26 newborns submitted to blood gases analysis and admitted to a Neonatal Intensive Care Unit. Data were collected in April and May 2010, by means of an identification form and physiological changes presented by newborns before and during the procedure.

RESULTS: There have been newborn facial manifestations of pain $(100 \%)$, heart rate changes $(50 \%)$ and decreased oxygen saturation $(34.7 \%)$.

CONCLUSION: When physiological parameters were compared before and during arterial puncture, there have been pain facial manifestations in all newborns as well as physiological changes such as decreased oxygen saturation levels and increased heart rate, according to the Neonatal Facial Activity Coding scale, showing that, although unable to verbalize, newborns are able to show changes expressing the pain felt at arterial puncture. The application of this scale was especially important for favoring sensitization and a holistic nursing care for painful newborns.

Keywords: Blood gases analysis, Newborn, Pain

1. Universidade Federal do Ceará, Departamento de Enfermagem, Fortaleza, CE, Brasil.

Submitted in February 22, 2015

Accepted for publication in July 27, 2015.

Conflict of interests: none - Sponsoring sources: none.

Correspondence to:

Isis de Oliveira Pinheiro

Av. dos expedicionários, $5405 \mathrm{Bl} 03 \backslash 403$

60410-234 Fortaleza, CE, Brasil.

E-mail: izinha_oliveira@hotmail.com

(c) Sociedade Brasileira para o Estudo da Dor

\section{RESUMO}

JUSTIFICATIVA E OBJETIVOS: Avaliar as respostas de dor dos recém-nascidos, submetidos à gasometria arterial, por meio da escala de Codificação da Atividade Facial Neonatal, assim como comparar os parâmetros fisiológicos do recém-nascido, antes e durante a punção arterial.

MÉTODOS: Estudo exploratório, descritivo e transversal, que avaliou 26 recém-nascidos em gasometria arterial, internados na Unidade de Terapia Intensiva Neonatal. Os dados foram coletados em abril e maio de 2010, a partir de um formulário de identificação para os recém-nascidos e as alterações fisiológicas apresentadas antes e durante o procedimento.

RESULTADOS: Constatou-se presença de manifestações faciais de dor nos recém-nascidos (100\%), alteração na frequência cardíaca (50\%) e redução da saturação de oxigênio (34,7\%).

CONCLUSÃO: Quando comparados os parâmetros fisiológicos do recém-nascido, antes e durante a punção arterial, constatou-se que houve presença de manifestaçóes faciais de dor em todos os recém-nascidos e alteraçóes fisiológicas como diminuição dos níveis de saturação de oxigênio e aumento da frequência cardíaca, de acordo com a escala Codificação da Atividade Facial Neonatal, demonstrando que, apesar de não verbalizar, conseguem demonstrar alteraçóes que expressam a dor sentida no momento da realização da punção arterial.A aplicação dessa escala foi importante, especialmentepara favorecer a sensibilização e um cuidar de enfermagem holística ao recém-nascido com dor.

Descritores: Dor, Gasometria, Recém-nascido.

\section{INTRODUCTION}

Child birth is an important event, with major repercussions in the family environment. Experts ${ }^{1,2}$ say that parents, especially mothers, suffer the burden of separation when unable to be close to their healthy baby, due to prematurity, hemodynamic instability or malformations, which are factors which may lead to newborn (NB) admission to the Neonatal Intensive Care Unit (NICU) ${ }^{1,2}$.

When admitted to the NICU, NB are constantly handled. It is estimated that they receive approximately 134 painful procedures during their first two weeks of life, or up to 14 painful procedures per day ${ }^{3}$. 
Among several painful procedures performed during NB stay in the NICU there are tracheal intubation, airway aspiration, orogastric probe, removal of adhesives, chest drainage, achievement of central lines, lumbar puncture, venous and arterial punctures ${ }^{4}$.

Blood gases analysis is a painful procedure, characterized as an invasive, critical and routine exam in neonatal units, performed in NB with respiratory disorders. Such exam provides values to analyze blood gases and body acid-base balance and is performed via arterial puncture

For a long time, NB pain was not considered reason for concern by clinical professionals and researchers, because it was believed that they were unable to feel pain. Currently, however, researchers have documented that NB have all functional and neurochemical components needed for pain reception and transmission ${ }^{6}$.

For such, scales were developed to allow NB measurement and identification of pain as the fifth vital sign. Among different pain scales, most widely studied are Neonatal Facial Activity Coding Scale (NFCS), Pain Evaluation Scale (NIPS) and Premature Infant Pain Profile (PIPP) ${ }^{7}$.

Pain evaluation should provide accurate data to determine actions to be taken to prevent, relieve or abolish pain and, at the same time, to evaluate the efficacy of such actions ${ }^{8}$.

In light of this set of ideas, there are questions such: which are $\mathrm{NB}$ responses to blood gases analysis, by means of the NFCS scale? Are there changes in NB oxygen saturation levels $\left(\mathrm{SatO}_{2}\right)$ and heart rate $(\mathrm{HR})$ during blood gases analysis?

The study is justified because the proposal is to identify facial manifestations and physiological changes during blood gases analysis, using a scale as measurement tool to characterize NB pain, thus proposing to be a facilitator tool for NICU nurses, to recognize NB pain manifestations during blood gases analysis. In addition to favoring qualification and sensitization of professionals so that they are qualified to evaluate and handle pain of NB admitted to the NICU.

The objectives were to evaluate responses of newborns submitted to blood gases analysis by means of the NFCS scale, as well as to compare NB physiological parameters before and during arterial puncture.

\section{METHODS}

This was an exploratory, descriptive and cross-sectional study carried out in the NICU of a teaching hospital of the State public network, reference in highly complex obstetric and neonatal assistance.

Participated in the study $26 \mathrm{NB}$ admitted to the NICU, who met inclusion criteria of the study: having up to 28 days of life; being admitted to the NICU, being monitored with pulse oximetry and with indication for blood gases analysis.

Data were collected in April and May 2010, by means of the NFCS scale and with the help of NB identification form, as well as the presence of sedation, oxygen therapy support, number of arterial puncture attempts and $\mathrm{SatO}_{2}$ and HR responses before and during procedure.
NFCS scale evaluates the presence or absence of pain as from eight facial movements: brow bulge, stretched mouth (horizontal/vertical), eyelids squeezed shut, taut tongue, deepening of naso-labial fold, tongue protrusion, open lips and chin quiver'.

Data were analyzed and interpreted as from relevant literature on the subject using descriptive statistics and were organized in tables.

Ethical-legal aspects of Resolution 466/2012 $2^{10}$ of the Department of Health were complied with and the study was approved by the Institution's Ethics Committee under protocol $390 / 2010$.

\section{RESULTS}

Categorical variables of newborns participating in the study were exposed for analysis of results, which are: days of life, gender, weight at birth, gestational age and Apgar score.

Table 1 shows distribution of NB participating in the study according to socio-demographic variables. With regard to gender there is equality being $50 \%$ females and $50 \%$ males. As to days of life there has been predominance $(80.8 \%)$ of one to seven days; and $92.3 \%$ were preterm neonates, that is, with gestational age between 20 and 37 weeks, which has contributed to high neonatal mortality indices.

Table 1. Sample characterization. Fortaleza, CE, Apr. May/2010

\begin{tabular}{|c|c|c|}
\hline Characteristics & $\mathrm{n}(26)$ & $\%$ \\
\hline \multicolumn{3}{|l|}{ Gender } \\
\hline Female & 13 & 50.0 \\
\hline Male & 13 & 50.0 \\
\hline \multicolumn{3}{|l|}{ Days of life } \\
\hline 1 to 7 & 21 & 80.8 \\
\hline 8 to 28 & 5 & 19.2 \\
\hline \multicolumn{3}{|l|}{ Gestational age } \\
\hline Preterm (<37weeks) & 24 & 92.3 \\
\hline Term (>37 to 41 weeks and 6 days) & 2 & 7.7 \\
\hline \multicolumn{3}{|l|}{ Weight at birth } \\
\hline Extremely low weight & 12 & 50.0 \\
\hline Very low weight & 7 & 29.2 \\
\hline Low weight & 4 & 16.6 \\
\hline Adequate weight & 3 & 4.2 \\
\hline \multicolumn{3}{|l|}{ Apgar score ( $5^{\text {th }}$ minute of life) } \\
\hline Without suffocation (8 to 10 ) & 13 & 50.0 \\
\hline Mild suffocation (5 to 7 ) & 13 & 50.0 \\
\hline \multicolumn{3}{|l|}{ Oxygen therapy support } \\
\hline Invasive mechanical ventilation & 23 & 88.5 \\
\hline Nasal CPAP & 2 & 7.7 \\
\hline Oxy-hood & 1 & 3.8 \\
\hline
\end{tabular}
hood. 
With regard to weight, $95.8 \%$ were born with lower weight than adequate for birth and from these, 50\% were classified as extremely low weight, varying from 455 to $970 \mathrm{~g}$, being important to stress the influence of this factor on morbidity, mortality and clinical complications during $\mathrm{NB}$ admission to the NICU.

There has been mean Apgar score of seven in the fifth minute, since all NB had Apgar scores in the fifth minute between 5 and 10, being classified as mild suffocation or no suffocation.

With regard to ventilatory support, there has been $88.5 \%$ invasive mechanical ventilations, followed by $7.7 \%$ of $\mathrm{NB}$ under nasal CPAP.

Major reasons for admission were: prematurity, found in $80.7 \%$ of $\mathrm{NB}$; respiratory distress syndrome (RDS) in $19.2 \%$, followed by cardiomyopathy to be explained, ischemic anoxia encephalopathy and seizures, congenital malformation and NB transient tachypnea in $3.8 \%$ of all NB (Table 2).

Table 2. Distribution of newborns according to face manifestations of pain by means of the Neonatal Facial Activity Coding scale. Fortaleza-CE, Apr-May/2010

\begin{tabular}{lcc}
\hline NFCS scale indicators & $\mathrm{n}$ & $\%$ \\
\hline Open lips & 25 & 96.1 \\
Brow bulge & 23 & 88.4 \\
Eyes squeezed shut & 20 & 76.9 \\
Stretched mouth & 17 & 65.4 \\
(horizontal or vertical) & & \\
Deepening of naso-labial fold & 16 & 61.5 \\
Tongue protrusion & 14 & 53.8 \\
Taut tongue & 6 & 23.1 \\
Chin quiver & 5 & 19.2 \\
\hline
\end{tabular}

Table 2 shows that, among NB facial manifestations during the exam, some were more frequent, such as: open lips, corresponding to $96.1 \%$ of newborns; followed by brow bulge, with $88.4 \%$ and eyes squeezed shut with $76.9 \%$.

Only two scale indicators had percentiles below $50 \%$, taut tongue and chin quiver. This fact may be associated to the difficulty in assessing NB tongue, since most of them were under invasive mechanical ventilation (IMV), thus being intubated. Data have shown that among eight NFCS scale indicators analyzed during blood gases analysis procedure, six of them were present in more than $50 \%$ of NB.

It has to be stressed that $96.1 \%$ had enough manifestations to characterize pain during blood gases analysis and just one NB had not such manifestations since he was under sedation, however different from the other NB who, in spite of being sedated, has shown some pain manifestations.

It should be emphasized that most NB had manifestations according to NFCS scale, showing that although being unable to verbalize, they are able to show behavioral and physiological changes to express pain felt during arterial puncture, thus going against the traditional idea that NB are unable to feel pain.

Table 3 shows physiological changes during blood gases analysis where it is observed that there have been changes in $\mathrm{HR}$ and $\mathrm{SatO}_{2}$.

Table 3. Distribution of newborns with regard to heart rate and oxygen saturation before blood gases analysis procedure. Fortaleza-CE, Apr-May/2010

\begin{tabular}{lcc}
\hline Physiological changes & $\mathrm{n}(26)$ & $\%$ \\
\hline Heart rate $(\mathrm{bpm})$ & & \\
130 to 145 & 4 & 15.4 \\
146 to 160 & 10 & 38.5 \\
$>160$ & 12 & 46.1 \\
Oxygen saturation (\%) & & \\
$<90$ & 5 & 19.2 \\
90 to 95 & 8 & 30.8 \\
96 to 98 & 13 & 50.0 \\
\hline
\end{tabular}

It was observed that $53.9 \%$ of NB had normal HR before blood gases analysis, that is, between 130 and 160 beats per minute; and $46.1 \%$ were already with tachycardia. As to $\mathrm{SatO}_{2}$, it has varied from 81 to $98 \%$, being that $50 \%$ had ideal saturation between 96 and $98 \%$. However, $19.2 \%$ had $<90 \%$ saturation (Table 4).

Table 4. Distribution of newborns with regard to changes in heart rate and oxygen saturation during blood gases analysis. Fortaleza-CE, Apr-May/2010

\begin{tabular}{lcc}
\hline Physiological changes & $\mathrm{n}$ & $\%$ \\
\hline Heart rate & 11 & 42.3 \\
Increased & 2 & 7.7 \\
Decreased & 13 & 50.0 \\
Remained equal to before procedure & & \\
Oxygen saturation & 2 & 7.7 \\
Increased & 7 & 27.0 \\
Decreased & 17 & 65.3 \\
Remained equal to before procedure & & \\
\hline
\end{tabular}

With regard to change in HR parameters, 50\% of newborns had changes in this vital sign during blood gases analysis, being that $42.3 \%$ have increased and $7.7 \%$ have decreased HR. As to $\mathrm{SatO}_{2}$, most (65.3\%) NN had no changes; however $34.7 \%$ have changed saturation, which could characterize pain during the procedure.

With regard to the number of puncture attempts, it has varied from one to four, being that in $19 \mathrm{NB}$ there has been success in the first attempt. However, it should be emphasized that in seven it was necessary 2 to 4 attempts to be successful, especially due to NB general clinical status, as well as to nurse's technical skills, thus the importance of nurses reflecting about the practice of humanistic care and prevention of pain when assisting NB at risk. 


\section{DISCUSSION}

For data analysis and discussion, references were used which characterized the importance of such data to sensitize health professionals acting in NICU when performing painful procedures in NB.

With regard to gender, there has been equal number of females and males. However, a study ${ }^{11}$ has shown a birth differential according to gender, with always a higher number of male births, regardless of the level of development of the studied area. A different study ${ }^{12}$ states that male gender was considered a risk factor for death, due to less maturity of organs and higher incidence of RDS, considered the major reason for NB admission to NICU; while there are higher survival rates among female NB.

Considering gestational age, there have been $92.3 \%$ of NB classified as preterm, or those with gestational age below 37 weeks.

As to weight, this is recognized as one of the best indicators of neonatal morbidity and mortality risk, since it is pertinent to say that 20 million low weight NB are born in the world every year, many as consequence of premature delivery, contributing to the high neonatal mortality rate still existing in several regions, especially in developing countries. Recent data refer that in Brazil, childhood mortality rate has considerably decreased in the last decades; however indices are still high: approximately 23.6 deaths per thousand births, especially due to prematurity and low weight at birth ${ }^{13}$.

When assessing Apgar scores in the fifth minute of life, it is observed that all NB had Apgar scores between 5 and 10, classifying them as mild suffocation (5 to 7 ) or no suffocation (8 to 10$)$, suggesting a positive prognosis with minor respiratory effort in the first minutes of life. The Apgar score provides accurate evaluation for the use of fast neonatal resuscitation procedures, still in the birthing room, because it has five parameters related to perinatal hypoxia such as: HR, breathing, muscle tone, reflex irritability and skin color, in a scale of zero to 10 and if score is below seven fetal hypoxia is diagnosed ${ }^{14}$.

As to respiratory support, it was observed that $88.5 \% \mathrm{NB}$ were under IMV, which could be associated to clinical instability and prematurity, thus justifying the need for respiratory support, which is vital to improve respiratory function and gases exchanges, especially for preterm NB. IMV is considered an invasive procedure predisposing NB to risks of iatrogenesis, bronchopulmonary dysplasia, infections and longer NICU stay. These circumstances may favor the possibilities of consequences arising from NB physiological conditions themselves or caused by therapy, environment and other factors, such as witnessing painful procedures such as blood gases analysis ${ }^{2,15}$.

Pain as a subjective sign, added to the difficulty in verbalizing it, conditions health professionals, especially NICU nurses, to be alert to behavioral and physiological changes following painful episodes. So, blood gases analysis is em- phasized as a painful procedure deserving further sensitization of health professionals to NB responses and then to use pain evaluation tools, such as facial mimic scale (NFCS) and intervene to relieve NB pain ${ }^{6}$.

So, it is important that NICU nurses provide holistic and humanized care to NB at risk during blood gases analysis procedures, that is, the assistance should not be exclusively directed to operational technical approaches, but also to a technology associated to reassurance ${ }^{16}$.

With regard to NFCS scores, most NB (96.1\%) had enough manifestations to characterize pain during blood gases analysis. However, it is important to emphasize that two were sedated, with only one showing pain characteristics according to NFCS.

A study ${ }^{7}$ has shown that there are no absolute indications for sedation and analgesia in the neonatal period, however stresses that it might be adequate for pain relief, especially for NB with potentially painful diseases and/or submitted to invasive procedures, surgical or not, such as chest drainage, elective tracheal intubation, patients with necrotizing enterocolitis and especially patients under IMV needing daily blood gases analysis.

Several physiological indicators may be used to evaluate, quantify and qualify pain. These variables include: heart and respiratory rates, blood pressure, $\mathrm{SatO}_{2}$, hand sweating, and vagal tone among others. However, such physiological indicators are not specifically related to pain ${ }^{17}$.

It was observed that $50 \%$ of newborns had $\mathrm{HR}$ changes during blood gases analysis and $34.7 \%$ have changed $\mathrm{SatO}_{2}$. Such findings are in line with authors ${ }^{18}$ who state that tachycardia is among most common human body responses to acute pain.

However, investigators ${ }^{17}$ refer that no significant changes in $\mathrm{HR}$ and $\mathrm{SatO}_{2}$ were observed before and after painful procedures, which indicates that $\mathrm{HR}$ and $\mathrm{SatO}_{2}$ alone to evaluate pain were not valid to identify NB submitted to a painful procedure.

During the exam, it was observed that $73 \%$ of NB undergoing blood gases analysis were successfully punctured in the first attempt; however seven of them needed two to four attempts, thus showing the importance of nurses technical skills, in addition to scientific knowledge related to NB anatomic and physiological conditions, such as sensibility and interaction with them, thus being able to notice facial and physiological manifestations during painful procedures. Other strategies may be used, such as placing the NB close to the mother to decrease pain, in addition to non-pharmacological interventions ${ }^{18}$.

As implication for assisting NB at risk admitted to neonatal unit, we believe it is of paramount importance the use of strategies to minimize NB pain during blood gases analysis. So, we suggest the use of behavioral scales to evaluate NB pain, such as NFCS. This scale allows professionals, when carrying out a painful procedure, to be sensitive to the onset of physiological or behavioral manifestations so as to minimize pain discomfort and complications from such manifes- 
tations. As limitation of our study, we stress the difficulty to generalize that the NFCS scale is adequate to evaluate NB pain during blood gases analysis, since such scale was used in association with physiological variables for such evaluation.

\section{CONCLUSION}

When NB physiological parameters were compared before and during arterial puncture, there have been face manifestations of pain in all NB, in addition to physiological changes such as decreased $\mathrm{SatO}_{2}$ levels and increased HR, according to NFCS scale, showing that although unable to verbalize they are able to show changes to express pain felt during arterial puncture.

\section{REFERENCES}

1. Campos AC, Cardoso MV. Enfermagem humanística: ênfase na comunicação com as māes de neonatos sob fototerapia. Petrópolis, RJ: EPUB; 2008. 12-20p.

2. Cruz AR, Oliveira MM, Cardoso MV, Lúcio IM. Sentimentos e expectativas da mãe com filho prematuro em ventilação mecânica. Rev Eletr Enf. 2010;12(1):133-9.

3. Brigitte L, Hogan DL, Gaboury I, Sherlock R, Blanchard C, Moher D. How effective is tetracaine $4 \%$ gel, before a venipuncture, in reducing procedural pain in infants: a randomized double-blind placebo controlled Trial. BMC Pediatrics. 2007;7(1):1471-2431.

4. Lélis AL, Farias LM, Rebouças CB, Cardoso MV. Health promotion and nurse facing newborn pain in the neonatal unit: an exploratory-descriptive study. Online Braz J Nurs. 2010;9(2). Disponível em: <http://www.objnursing.uff.br/index.php/nursing/ article/view/j.1676-4285.2010.2996>. Acesso em: 13/7/2015.

5. Silva TM, Chaves EM, Cardoso MV. Dor sofrida pelo recém-nascido. Esc Anna Nery
Rev Enferm. 2009;13(4):726-32.

6. Sousa BB, Santos MH, Sousa FG, Gonçalves AP, Paiva SS. Avaliação da dor como instrumento para o cuidar de recém-nascidos pré-termo. Texto Contexto Enferm. 2006;15(n.esp):88-96

7. Guinsburg R. A Linguagem da dor no recém-nascido. São Paulo (SP): Sociedade Brasileira de Pediatria; 2000. Disponível em: http://www.sbp.com.br/src/uploads/2015/02/doc_linguagem-da-dor-out2010.pdf. Acesso em: 13/7/2015.

8. Raquel A C, Roberta C. Métodos não farmacológicos para alívio do desconforto e da dor no recém-nascido: uma construçáo coletiva da enfermagem. Texto Contexto Enferm. 2014;23(1):185-92.

9. Grunau RV, Craig KD. Pain expression in neonates: facial action and cry. Pain.1987;28(3):395-410.

10. Brasil. Conselho Nacional de Saúde. Resolução nº466/2012. Atualização da Resolução no 196/96 que estabelece critérios sobre pesquisa envolvendo seres humanos. Bioética em 1996. 2012. (bvsms.saude.gov.br/bvs/saudelegis/cns/2013/res0466_12_12_2012. html).

11. Carvalho AB, Brito AS, Matsuo T. Assistência à saúde e mortalidade de recém-nascidos de muito baixo peso. Rev Saúde Pública. 2007;41(6):1003-12.

12. Pinheiro AS, Sá FE. Efeitos da aspiração de vias aéreas no comportamento de prematuros submetidos á ventilaçấo mecânica publicado em 24 de julho de 2006. Disponível em: http://www.fisiorespiratoria.com.br/artigos.asp> Acesso em: 15.06.2010.

13. Gomela TL. Neonatologia: manejo, procedimentos, problemas no plantão, doenças e farmacologia neonatal. 5a ed. Porto Alegre: Artmed; 2006. 374-8p.

14. Chalfun G, Mello RR, Dutra MV, Andreozzi VL, Silva KS. [Risk factors for respiratory morbidity at 12 to 36 months in very low birth weight premature infants previously admitted to a public neonatal intensive care unit]. Cad Saude Publica. 2009;25(6):1399-408. Portuguese.

15. Rolim KM, Cardoso MV. [Interaction nurse-newborn during orotracheal aspiration and blood collection]. Rev Esc Enferm USP. 2006;40(4):515-23. Portuguese.

16. Nicolau CM, Modesto K, Nunes P, Araújo K, Amaral H, Falcão MC. Avaliação da dor no recém-nascido prematuro: parâmetros fisiológicos versus comportamentais. Arq Bras Ciênc Saúde. 2008;33(3):146-50.

17. Guinsburg R, Kopelman BI, de Almeida MF, Miyoshi MH. [Pain in intubated and ventilated preterm neonate: multidimensional assessment and response to fentanyl analgesia]. J Pediatr. 1994;70(2):82-90. Portuguese.

18. Correia LL, Linhares MB. [Assessment of the behavior of children in painful situations: literature review]. J Pediatr. 2008;84(6):477-86. English, Portuguese. 